\title{
DIAMETER DISTRIBUTION OF BALSAM FIR ON TWO SITE-TYPES IN QUEBEC
}

\author{
BY P. E. VEZINA ${ }^{1}$
}

Diameter distributions have been used extensively as a characterization of the forest stand. Various methods, such as the "Méthode du contrôle" (Meyer et al. 1952) and the stand table projection methods (Smithers 1949) characterize growth by diameter classes. This note reports on an attempt to describe diameter distribution in even-aged unmanaged balsam fir (Abies balsamea (L.) Mill.) stands growing on two site-types commonly found in the Boreal Forest Region (Rowe 1959) of Quebec.

Diameter distributions from 67 plots of balsam fir were determined. These plots, installed during 1959-64, consisted of rectangular 1/5-acre plots established in fully-stocked even-aged balsam fir stands growing on two sitetypes: the Dryopteris-Oxalis (26 plots) and the Hylocomium-Oxalis ( 41 plots) site-types (Linteau 1955). Ages ranged from approximately 30 to 90 years, site indexes from 35 to 55 feet at 50 years and average stand diameters from 1.6 to 6.5 inches. Plots were located in the Laurentide Park and adjacent areas north of Quebec City.

The distribution of number of trees per acre in each dbh class was calculated separately for each plot, and average distributions were derived for each average stand dbh within a given site-type. The percentage distributions of number of trees in each dbh class were then plotted on logarithmicprobability paper.

Figure 1 shows the percentage distribution of the number of trees by dbh classes for fully-stocked stands of the two site-types. With this figure it is possible to find the proportion of number of trees in any diameter class, group of diameter class, or above or below any diameter limit.

The differences in the distribution of stems among the two site-types result from a greater number of small trees in stands of the Hylocomium-Oxalis sitetype at a given average $\mathrm{dbh}$ as compared with the Dryopteris-Oxalis site-type. Young stands of the former site-type originating after clearcutting or windfall commonly form dense thickets whereas those of the latter site-type tend to be understocked due to heavy competition from shrubs and low-quality hardwoods.

The straight lines in Figure 1 seem to indicate that the distributions were normal, but this was not the case. In fact, there was some weaving about the lines and the dominant trend was concave downward, which imply that on the average the stands had excess percentages to the left. However, the straight lines in Figure 1 are thought to be sufficiently accurate for use in forest inventory work. A description of some of the distributions found in sampling forest stands has been given by Smith and Ker (1957).

The frequency distributions in Figure 1 can be used to construct stand tables by numerical (Meyer 1930) or graphic (Bliss and Reinker 1964) analysis. Stand tables showing for various site-types the number of trees in each

\footnotetext{
${ }^{1}$ Professor of Silviculture, Dept. of Forestry, Laval University, Quebec City, Que.
} 


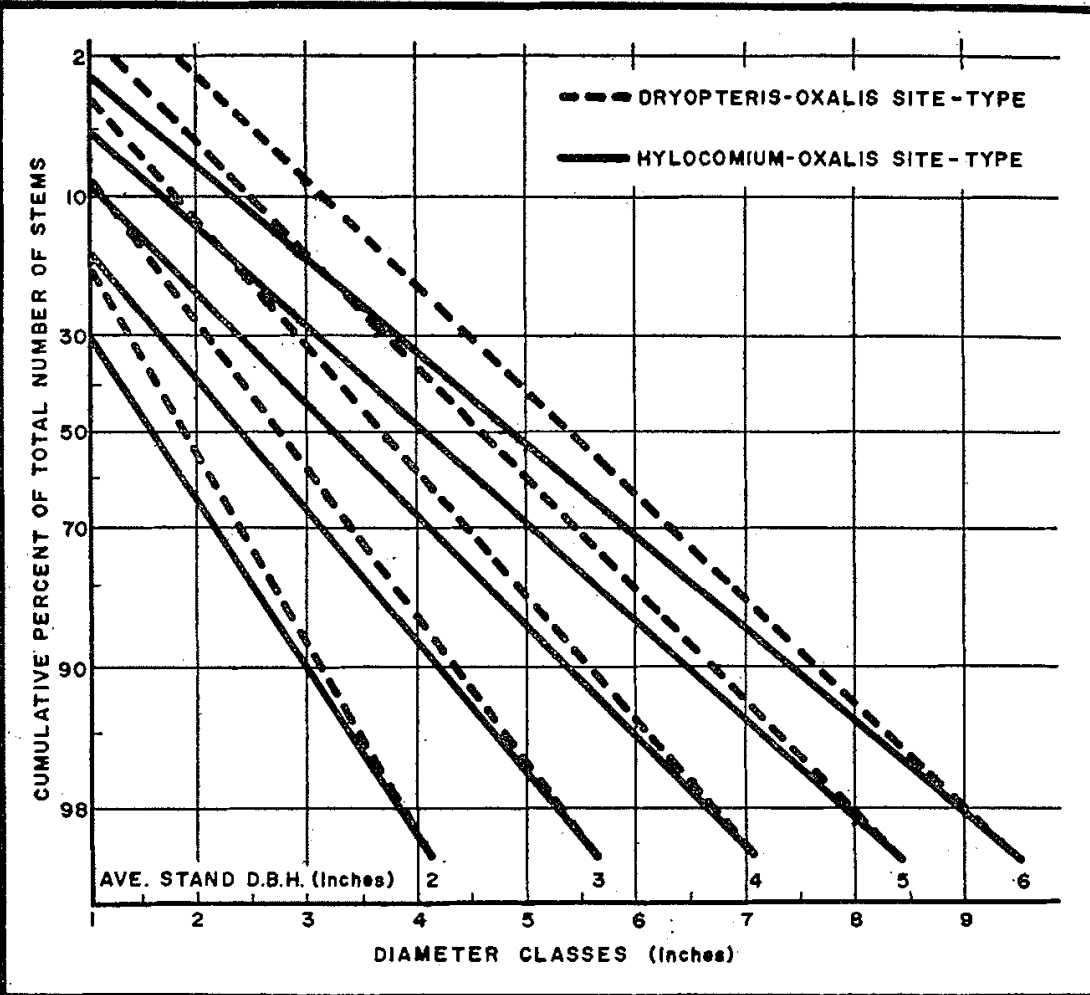

FIGURE 1. Cumulative stand distribution for fully-stocked unmanaged balsam fir stands of the Dryopteris-Oxalis and the Hylocomintm-Oxalis site-types.

dbh class at various periods in the life of balsam fir stands from 20 to 100 years of age are in preparation. Analyses will be extended in time to other commercial species of Quebec.

\section{REFERENCES}

BLISS, C. I. and K. A. REINKER. 1964. A Iognormal approach to diameter distributions in even-aged stands. Forest Science 10:350-360.

LINTEAU, A. 1955. Forest site classification of the Northeastern Coniferous Section, Boreal Forest Region, Quebec. Canada Dept. of North Aff. and Nat. Res., Forestry Branch, Bull. No. 118. ix +85 p.

MEYER, W. H. 1930. Diameter distribution series in even-aged forest stands. Yale Uniq. School of Forestry Bull. 28. 105 p.

MEYER, H. A., A. B. RECKNAGEL and D. D. STEVENSON. 1952. Forest Management. The Ronald Press Co., New York. 290 p.

ROWE, J. S. 1959. Forest Regions of Canada. Canada Dept. North. Aff. \& Nat. Res., Forestry Branch, Bull. No. 123.71 p.

SMITH, J. H. G. and J. W. KER. 1957. Some distributions encountered in sampling forest stands. Forest Science 3: 137-144.

SMITHERS, L. A. 1949. The Dwight cofrequency principle in diameter growth analysis. Canada Dominion Forest Serv. Silvic. Res. Note 91. 26 p. 